Erratum

\title{
Erratum: Mohammad Shibli Kaysar and Mohammad Ibrahim Khan A Modified Median String Algorithm for Gene Regulatory Motif Classification Symmetry $2020,12,8$
}

\author{
Mohammad Shibli Kaysar * and Mohammad Ibrahim Khan \\ Department of Computer Science and Engineering, Chittagong University of Engineering and Technology, \\ Chittagong 4349, Bangladesh; muhammad_ikhan@cuet.ac.bd \\ * Correspondence: shibli@iub.edu.bd
}

Received: 28 August 2020; Accepted: 28 August 2020; Published: 30 August 2020

check for updates

The authors wish to make the following corrections to their paper:

After 3.5. Proposed Algorithm, "Markow" in the title of Algorithm 2 should be changed to "Markov."

The changes do not affect the scientific results. The manuscript will be updated and the original will remain online on the article webpage, with a reference to this correction.

C 2020 by the authors. Licensee MDPI, Basel, Switzerland. This article is an open access article distributed under the terms and conditions of the Creative Commons Attribution (CC BY) license (http://creativecommons.org/licenses/by/4.0/). 